\title{
Sikertelen kísérlet?
}

\section{Földreform és telepítés a Monarchia romjain}

Szakál Imre: Telepesek és telepes falvak a csehszlovák Kárpátalján. MTA TK Kisebbségkutató Intézet Kalligram, Budapest, 2017.

Magyarországgal szomszédos országok az első világháborút
követő földreformjait és telepítési politikáit bemutató jelenkori
feldolgozások, monográfiák újabb darabja látott napvilágot a
beregszászi II. Rákóczi Ferenc Kárpátaljai Magyar Főiskola
oktatójától, aki a Debreceni Egyetemen megvédett doktori
disszertációját dolgozta át monográfiává.
Szakál Imre kötete (elörebocsátom) igen fontos mozaikdarabként
illeszkedik a kelet-közép-európai földreformokat, illetve az etnikai
indíttatású Kárpát-medencei telepítéseket feldolgozó tanulmányok és
monográfiák sorába. Az elmúlt bő egy évtizedben élénk érdeklödés
mutatkozott a szomszédos országok első világháborút követő
telepítései iránt. Mivel a jelenkori feldolgozások, így Kovács Attila
és Simon Attila munkáinak (akik egyébiránt e kötet lektorai is

1 A szerző történész, az MTA Társadalomtudományi Kutatóközpont Kisebbségkutató Intézetének könyvtár-informatikusa. Email: hegedus.istvan@tk.mta.hu.

2 Lásd: Kovács Attila: Földreform és kolonizáció a Lendva-vidéken a két világháború között. Lendva, 2004. és Simon Attila: Telepesek és telepes falvak Dél-Szlovákiában a két világháború között. Somorja, Fórum Kisebbségkutató Intézet, 2009. A témához szorosan kapcsolódónak tekintem Mák Ferenc tanulmányát is: A délvidéki kolonizáció és az agrárreform (1918-1941). In: Mák Ferenc: Vesztegzár. Méry Ratio-Kisebbségekért-Pro Minoritate Alapítvány, 2013. 5-84.

REGIO 26. évf. (2018) 1. szám 120-130. 
voltak) hasonló szerkezete, a kötetek felépítése lehetővé teszi, érdemes lehet azonos szempontok szerint összehasonlítani öket. ${ }^{3}$

A sort Kovács Attila kötete nyitotta, melyben a Szerb-HorvátSzlovén Királyság Lendva-vidéket is érintő földreformját, annak következményeit vizsgálta. Simon Attila 2009-ben megjelent, széles körü forrásfeltáráson alapuló munkájában a kolonizáció folyamatának bemutatása a hangsúlyosabb (hasonlóan Szakál Imre jelen kötetéhez).

A historiográfiai bevezetőket és a fogalmak tisztázását követően pillanatképet festettek a háború előtti népszámlálások eredményeiről, a nyelvhatárok és földbirtokviszonyok változásáról. A többségi politikai pártoknál teljes egyetértés mutatkozott a földreform szükségességét illetően (noha programszinten kevés konkrétum jelent meg), legfeljebb az árnyalatok különböztek. A pártok, bár nagyrészt a saját helyük és választóik keresése, a határozatlanság jellemezte őket, ráadásul egy-egy párton belül ellentmondásos volt a kommunikáció, a telepítéssel mind egyetértettek. A földreform és a telepítés, vagy összefoglalóan agrárkérdés egyben kulcskérdés is volt az újonnan létrejött államalakulatok számára, már csak a belső ellátási rendszerek megszervezése miatt is. ${ }^{4}$

1919-et követően rövidesen minden szomszédos országban megszülettek a hitbizományok felosztását kihirdető rendeletek és törvények. Lendva-vidéken a földminimum 42 hektár ${ }^{5}$ volt, míg nagybirtoknak 72 hektár müvelhető és 192 hektár összterület felett tekintették a birtoktesteket. ${ }^{6}$ Csehszlovákiában, így Kárpátalján is

3 A Kárpát-medence országaiban az első világháborút követően végrehajtott földbirtokrendezések alapos összehasonlítását Bartha Ákos végezte el: A két világháború közti csehszlovák, jugoszláv és román földbirtokrendezés. Valóság, 2012. 10. 96-112.

${ }^{4}$ Kovács, 2004. 114.

${ }^{5}$ A szövegben következetesen a hektár mértékegységet használom. Amennyiben a hivatkozott szövegben kataszteri hold szerepel, úgy azt hektárra váltom át, korunk olvasójára, valamint a felhasznált szövegekben is tapasztalható következetlen használatra tekintettel. 1 kataszteri hold $=0,55$ hektár (továbbiakban ha).

${ }^{6}$ Romániában, a korábban Magyarországhoz tartozó országrészeken, hegyvidéki területnél 27,5 ha, dombvidéknél 55 ha, síkvidéki területen 110 ha volt a földmaximum. A regáti szabályozási környezet jóval nagyobb mozgásteret biztosított a tulajdonosoknak. Bartha, 2012. 103.

REGIO 26. évf. (2018) 1. szám 120-130. 
lefoglaltak minden 150 hektár feletti mezőgazdasági vagy 250 hektár feletti földterületet. ${ }^{7}$ A törvények és rendeletek kihirdetését követően azonban rögtön megtorpant a reformok lendülete. Lendva-vidéken a nagybirtokok négy évre történő bérbeadásával a kérdést sikeresen elodázta a kormányzat, ${ }^{8}$ a földmaximumok kihirdetésével pedig még az ellenérdekelt pártokat is részint megnyerte magának. Ezt tetézte az az 1925-ben elfogadásra került rendelet, melynek értelmében miniszteri engedéllyel a földmaximum feletti rész eladható vált. ${ }^{9}$ Csehszlovákiában a Földhivatal szervezeti felépítése akadályozta az első években a folyamatot. Bár a reform, ahogy azt Simon Attila is hangsúlyozta kötetében, nagyban elösegítette a társadalmi egyenlőtlenségek lebontását, mégis sok negatívummal járt (nagybirtokos alkalmazottak munkavesztése, vagy például a pártokhoz közeli agrárvállalkozók vagyonának és befolyásának aránytalan növekedése).

Kovács Attila munkájánál kiemelendő, hogy egy kimunkált esettanulmányt is ad (amelyben a muravidéki Esterházyuradalommal foglalkozott) és ennek segítségével pontosabb és jobban illusztrált képet kaphatunk a földreform mindennapi életet érintő, tényleges hatásairól. Többek között kiderül, hogy a reform a közbirtokossági szerződések miatt sok községben már évekkel a törvénybeli rendezés előtt lezajlott, így az érintettek legfeljebb megerősítést vártak/várhattak az új szabályozási környezettől. A feldolgozásokból egyértelmüen kiderül, hogy a legnagyobb ellenállást az okozta, hogy az állam két magánjogi szerződő fél közé lépett be, ezáltal kiszámíthatatlan jogi körülményeket hozott létre. ${ }^{10}$

A kolonizáció szabályozásai kezdetben az önkéntesek és a más országrészekből menekültek földhöz juttatását segítették, később azonban már tudatos telepítésre irányultak. A végrehajtás szinte kivétel nélkül a helyi szinteken levő agrárbizottságok feladata volt, így a konfliktusok is helyi szinten maradtak. A korábbi döntések

\footnotetext{
${ }^{7}$ Simon, 2009. 36.

8 Több mint öt évig húzódott az eredeti birtokosok használatában maradó területek kijelölése, egészen 1928. júliusig.

${ }^{9}$ Kovács, 2004. 140.

${ }^{10} \mathrm{Az}$ sem elhanyagolható körülmény, hogy sok esetben a magyar családok a későbbi szlovén tulajdonosaiktól bérelték vissza a korábban az Esterházyaktól bérelt földjeiket. Kovács, 2004. 313.
}

REGIO 26. évf. (2018) 1. szám 120-130. 
megmásításával a hatóságok sokszor még a telepeseket is lehetetlen helyzetbe hozták. $^{11}$

A földreformok és telepítések következményeit összegezve feltehető a kérdés: milyen eredményei voltak a földreformnak és a telepítéseknek? A Szerb-Horvát-Szlovén Királyság ${ }^{12}$ területén új tulajdonba került 2,2 millió ha föld, melyet 600.000 család között osztottak fel. ${ }^{13} 1931$ márciusáig 221 család 5 településen telepedett le a Lendva-vidéken. ${ }^{14}$ Csehszlovákia szlovákiai területén valamivel több mint 690.000 hektár került új tulajdonba. ${ }^{15}$ A telepítések eredményeként pedig több mint 3300 család 144 kolónián talált - ha csak rövid ideig is - otthonra, amely már egy szükebb régióban (DélSzlovákia) képes lehetett komoly etnikai változások megindítására. ${ }^{16}$

Szakál Imre könyve a Csehszlovák Köztársaság kárpátaljai telepítéseire fókuszál, amelyet három nagyobb fejezetben, ezen belül 9 kisebb alfejezetre tagolva tekint át. Elöbb a szigorúan csak Kárpátaljára vonatkozó historiográfiai elözményeket (mely azért is dicséretes, mert az „össz-csehszlovák” vonatkozásokat kiválóan dolgozta fel Simon Attila monográfiája), majd a földreform és a kolonizáció helyi vonatkozásait (ez a munka tulajdonképpeni gerince), utoljára pedig a telepítések politikai és etnikai következményeit. A földreformot bevallottan röviden tárgyalja (már csak azért is, mert a földbirtokszerkezetben bekövetkezett változások bemutatásához kevesebb információ áll rendelkezésre); a középpontban a telepítések és a telepesek sorsa áll. A kötet jól szerkesztett, megfelelően illeszkedik napjaink olvasói elvárásaihoz, követi a REGIO-Könyvek sorozat korábban megszokott formavilágát. Az olvashatóságot kevés elütés zavarja.

\footnotetext{
${ }^{11}$ Ahogy Kovács Attila írja: „az állami adminisztrációt addig a térségben soha nem tapasztalt módon közvetlen beavatkozásra használták fel a magánszféra területén egy állameszme megvalósulásának kierőszakolására”. Kovács, 2004. 277.

${ }^{12}$ Illetve 1929-től hivatalosan Jugoszlávia.

13 A legtöbb birtokbaadás az újonnan létrejött államalakulat déli régióiban történt, északon jellemzőbb volt a parcellakiegészítés. Kovács, 2004. 180.

${ }^{14}$ Kovács, 2004. 292.

${ }^{15}$ Simon, 2009. 46.

${ }^{16}$ Simon, 2009. 169.
}

REGIO 26. évf. (2018) 1. szám 120-130. 
Kárpátalja (hivatalos nevén Podkarpatszka Rusz), mint közigazgatási egység létrejöttét követően még évekbe telt, mire a csehszlovák állami kormányzat konszolidálni tudta a közigazgatási viszonyokat. A földreform Kárpátalja tekintetében a közel 1,1 millió ha terület negyedét érintette, melyből mezőgazdasági művelés alá mindössze 58.300 ha terület esett. ${ }^{17}$ A nagybirtokok aránya (bár erről csak egy 1895-ben publikált birtokösszeírás áll rendelkezésre és az 550 ha feletti birtokokra értendő) az összes földterület picivel több mint harmada volt, így inkább azok relatív többségéről, mint a szerző által említett jellemző voltáról beszélhetünk. ${ }^{18}$

Kárpátalján a lakosság 66\%-a élt mezőgazdaságból, ${ }^{19}$ ezek közül a ruszin (82\%) és a magyar (57\%) nemzetiségüek aránya volt a

${ }^{17}$ Kárpátalja teljes területének 32\%-a volt mezőgazdasági termelés alá vonható, 49\%-a erdőség. A szlovákiai országrész összterületének 28,7\%-át, körülbelül 1,4 millió ha-t foglaltak le, melynek mezőgazdasági művelés alá voható 507.000 ha területéből 323.000 ha került új tulajdonosokhoz 1937 végéig. Simon, 2009. 46. Romániában picivel több mint 3,3 millió ha-t osztottak ki majd másfél millió igénylö között. Bartha, 2012. 105.

18 Magyarországon az első világháborút követő 1920. évi földreformmal 616 ezer ha-t, a teljes termőterület 8,5\%-át vették igénybe és osztották szét, családtagokkal együtt másfél millió igénylő között. Sipos, 2010. 78. Összehasonlításul lásd: Csehszlovákiában, 1921-ben a 100 ha fölötti nagybirtokok száma az összes birtok 0,9\%-a, míg összes területük a teljes mezőgazdasági terület 31\%-a volt. Ezek az arányok 1931-ben 1\% és 26\% körül alakultak. Simon, 2009. 48. Romániában 1930-ban ez az arány 0,4\% és 27,7\% volt a teljes területre vetítve. Bartha, 2012. 105. Erdélyben 1929-ben a mezőgazdasági terület 14,6\%-a volt 100 hektár fölötti nagybirtok. Dolmányos, 1963. 496. Magyarországon ez az arány 1935-ben, tehát a 20-as évek földrendezéseit követően, $0,4 \%$ és $43 \%$ volt. Magyarország földbirtokosai és földbérlői, 1937. Jugoszláviában az 1931. évi összeírás szerint a 100 hektáron felüli nagybirtokok a teljes mezőgazdasági terület (erdők beszámítása nélkül és annak ismeretében, hogy az adatgyüjtés nem terjedt ki a teljes államterületre) 10\%-át fedték le. Dolmányos, 1964. 360.

19 Csehszlovákiában az összlakosság 39,6\%-a, míg a magyar nemzetiségűek 61,2\%-a élt mezőgazdaságból. Simon, 2009. 49. Lendva-vidéken a lakosság $72 \%$-a volt őstermelö, a döntően mezőgazdasági jellegü terület miatt is. Kovács, 2004. 83. Az 1910-es népszámlálási adatok szerint Szerbia népességének 84\%-a élt a mezőgazdaságból. Mák, 2013. 20. Romániában az 1930-as népszámlálási adatok alapján a teljes lakosság 72,3\%-a foglalkozott östermeléssel, míg Erdélyben a magyar lakosság átlagosan 58\%-a. Opra Pál: Erdély lakosságának

REGIO 26. évf. (2018) 1. szám 120-130. 
legmagasabb. Gazdaság- és szociálpolitikai tekintetben tehát, mivel épp ezeket a nemzetiségeket érintette legfőképpen hátrányosan (38.), a földreform intézkedései semmiképp sem nevezhetőek „arányosnak”. Fontos és értékes adalék lehetett volna ezen lakosság földbirtokméret szerinti csoportosítása és bemutatása is.

A földbirtokok lefoglalása és parcellázása a legnagyobb birtokokon kezdődött meg. Azonban mindez hasonlóan más, a földreformot végrehajtó országokhoz, Kárpátalján is rendkívül lassan haladt. A lefoglalt területek aránya átlagosan még 1932-ben is alig $19 \%$ volt (46.). Sajnálatos, hogy a szerző nem jut túl ezen birtokok részleges felsorolásán (noha birtokméret szerint szemlélteti a lefoglalt területeket a 48. oldalon levő táblázatában) még egy rövidebb esettanulmány mélységü elemzés erejéig sem, noha azt gondolom, hogy a földreform általi ,igénybevétel” mértéke csakis ezen birtokok pontosabb adatainak feltárásával képzelhető el.

A földreform magyarokat hátrányosan érintő etnikai színezete markáns kutatási pontként szerepelt a korábbi vizsgálatokban is. Jelen kötet földreformot tárgyaló alfejezetében két bekezdés foglalkozik a témával (49-50.), később viszont egy teljes fejezetet szentel a szerző a földreform és a telepítések nemzetiségi következményeinek. Noha több, egymásnak ellentmondó adatot tárt fel, ${ }^{20}$ azok értelmezését nem végezte el. A korabeli politikai program része, a korábbi szakirodalom, valamint a szerző saját kutatási tapasztalata alapján is a földreform vezérfonala volt a „domináns földbirtokos elitek gyengítése, és a kiutalások során az államalkotó nemzetiséghez tartozó igénylők előnyben részesítése a korábbi többségből kisebbséggé lett lakossággal szemben” (32.). A kárpátaljai földreformot bemutató alfejezet egy 11 oldalas táblázattal zárul (53-63.), mely a földreform által érintett települések és birtokosok listáját tartalmazza. Ez esetben bizonyosan informatívabb

foglalkozások szerinti megoszlása az 1930-as népszámlálási adatok alapján. Pro Minoritate, 2010. nyár 29-40. 29.

20 Míg Simon Attila kötete az Állami Földhivatal statisztikáira hivatkozva 23,6\%-nyi magyarok számára kiosztott földbirtokról és 21,8\% kiutalt birtokterületröl ír, addig más, föként 1938-1945 között megjelent kiadványok (például a szerző által is hivatkozott A felvidéki magyarság húsz éve 1918-1938. Budapest, 1938., valamint Jócsik Lajos: A Közép-Dunamedence közgazdasága. Budapest, 1944.) nagyságrendileg kisebb arányokról tudósítanak.

REGIO 26. évf. (2018) 1. szám 120-130. 
lett volna, ha a földbirtokos szerinti csoportosításban, a birtokok mérete is szerepelt volna a táblázatban.

Szakál Imre jól él a szintetizálás eszközével is, munkája földreformot leíró részébe igen alaposan építette be a szakirodalom eredményeit. Erőteljes elemző vénával is bír, melyet különösen a telepítésekkel kapcsolatos alfejezetekben kamatoztatott.

Amennyiben a földreformot etnikai célzatú rendeletsorozatnak minősítjük, többszörösen igaz ez a csehszlovák telepítési gyakorlatra. ${ }^{21}$ A telepítésekkel foglalkozó alfejezetek (”A telepítés vagy kolonizáció” és „Az állami és magántelepítések”) kapcsán fontos megjegyeznem, hogy mindenképp összevonhatóak lettek volna. Míg előbbi a telepítési tervekről, utóbbi a konkrét telepítésekről szól. További hiányérzetet kelthet, hogy míg a magántelepítések aránya nagyobb volt a szerző kutatásai szerint is (82.), az mégis alig két oldalt kap a teljes alfejezetből.

$\mathrm{Az}$ állami telepítések eredményeként Kárpátalján több szakaszban összesen 289 család (nagyjából 1200 fó), magántelepítések során további 317 család szerzett telket és földet a 21 létrehozott kolónián. További érdekes vizsgálati kérdést jelenthetett volna, hogy milyen motivációkkal zajlottak a magántelepítések, hogyan és milyen módon történhetett a magántelepítések finanszírozása, illetve melyik forma (állami vagy magán) biztosíthatott nagyobb sikerességet a telepesek számára.

A telepesfalvak mindennapjaival foglalkozó alfejezetből kiderül, hogy az intézkedések, bár komoly állami és politikai támogatottsággal indultak, a rendelkezésre álló szükös források miatt hamar lelassultak és befejeződtek. A legtöbb helyen még évekkel a telepítéseket követően is gondot okozott az alap-infrastruktúra hiánya, a gazdasággal való kapcsolódási pontok megteremtése. Talán elöbbieknél is aggasztóbb volt a telepesek által felvett hitelek visszafizetésének elmaradása. Az 1930-as évek elején a telepesek 100\%-a képtelen volt fizetni a hiteleit (114.). A körülmények megoldatlansága, a tiltakozó kérelmek folyamatossága miatt gyakoriak voltak ugyan az ideiglenes adómentesítések, de ezek sem tudták a tervezés és kivitelezés hiányosságait pótolni. Ezen a ponton

${ }^{21}$ Lásd a kötet 65. oldalán olvasható részleteket egy állami instrukció, valamint egy, a telepesek által készített határozat szövegezésében.

REGIO 26. évf. (2018) 1. szám 120-130. 
érdemes megjegyezni, hogy e fejezet megállapításait tovább árnyalhatták volna a helyi vagy országos sajtóban megjelenő tudósítások, összegzések.

Kárpátalja Csehszlovákiához csatolását követően minden országos párt létrehozta saját regionális képviseletét és szervezetét. Ezen pártok programjában közös elemként jelent meg a saját etnikai csoport védelme és az autonómiához való viszony. A földreform nemzetiségeket érintő aránytalanságai, majd a telepítések és a telepesek támogatásának csökkenése miatt egyik helyi párt sem volt elégedett a kormányzati tevékenységgel. Ezt tetézte a világválság hatásainak mérséklésére sem a földreform, sem más állami program nem talált megoldást (136.).

$\mathrm{Az}$ újonnan alakult Csehszlovákiának a csatolt régiók konszolidációja mellett alapvető célja volt az etnikai alapú földreform és az etnikai arányok megváltoztatása. Ahogy a kötet 137. oldalán is olvashatjuk: „Kárpátalja belső politikai és társadalmi konszolidációjának elősegítése." Az 'Etnikai következmények' c. fejezet következtetései alapján elmondható, hogy az arányok egyik, telepítés által érintett településen sem változtak 10\%-nál nagyobb mértékben. Szakál hasonló eredményre jut, mint korábban Kovács Attila Lendva-vidék és Simon Attila Dél-Szlovákia vonatkozásában: Kárpátalján a csehszlovák kormányzat eredeti, a magyar etnikum tömbjeinek fellazítására szolgáló céljai nem valósulhattak meg, sorra elbuktak a telepítések magas költségein (145.).

Kárpátalja revízióját követően rengeteg panaszos levél érkezett a magyar kormányhoz, melyek a korábbi földreform vélt igazságtalanságait sorolták. A tényleges jogi revízióra azonban a háború végéig sem került sor, noha rendelettervezetek sokasága keletkezett. Tehát nemcsak a csehszlovák földreform és telepítéspolitika, hanem annak revíziója sem érte el célját. Fontos kiemelnem, hogy a szerző további vizsgálatokat megelőlegező kérdéseket és kutatási irányokat is felvillant munkája végén. ${ }^{22}$ A kötetet rendkívül informatív háromnyelvü településjegyzék zárja.

$\mathrm{Az}$ előbbiekben felsorolt és érzékelhető hiányokkal együtt úgy gondolom, hogy Szakál Imre kötete kiválóan adatolt, informatív,

${ }^{22}$ Lásd Újakli település példáját, ahol épp elmagyarosodás történt, ellentétben a többi telepes községgel.

REGIO 26. évf. (2018) 1. szám 120-130. 
olvasmányos munka, mely nem kizárólag a szaktudomány érdeklődésére tarthat számot.

A Monarchia utódállamainak földreformjait összevetve megállapítható, hogy bár céljaikban nem, azok megvalósításában különbségek fedezhetőek fel. Noha Csehszlovákiában is a kisparaszti gazdaságok megerősítése, azok számának növelése volt a reformok fő célkitüzése, a megvalósítás során mégis a középbirtokos réteg kapott kiemelt támogatást, melynek nyomán a szociális célok elsikkadtak. Romániában országrészekre szabott, egyedi rendelkezések szabályozták a földreformot, melyek kiemelkedően sújtották a többségében magyarok lakta területeket (például a kisajátítás felső határának megszabásával, illetve a kárpótlás nélküli elkobzásokkal). Jugoszláviában szintén régiós eltérések mutathatók ki a földreform rendelkezései alapján, továbbá elmondható, hogy egyedüliként itt került sor a nemzeti kisebbségek földosztásból való jogszabályban rögzített kizárására. A többségében magyarok lakta területeket érintő telepítési akciók tekintetében hasonló arányokat találunk (100-150 kolónia létrehozása 3-5.000 családdal) DélSzlovákia és Erdély tekintetében. Kiemelkedik azonban Jugoszlávia, ahol majd 20.000 délszláv család letelepítésére került sor (többségében a Vajdaságban, a szlovéniai Lendva-vidéken ezzel szemben 221 család). ${ }^{23}$

A régió problémáira az impériumváltást követően sem talált megoldást a kormányzó elit, az új államalakulat, így Csehszlovákia sem. A földreformok végrehajtása, a birtokreform végtelenül túlbürokratizáltan folyt, végül épp emiatt, az állami szerveket megkerülve, adás-vételek következtében-követhetetlenné is vált.

A földreform és a telepítések eredményeként a régió birtokstruktúrája nem alakult át, a kis- és közepes gazdaságok nem erösödtek meg, a nagybirtokok részleges felosztása pedig a mezőgazdasági termelés színvonalának hanyatlásához, a termelés visszaeséséhez vezetett. A földreform helyiek nagy részét kizárta a földhöz jutásból, a telepesek életképtelenek voltak. Bár a földreform és a telepítés célja Kárpátalján is (hasonlóan Dél-Szlovákiához és

${ }^{23}$ Simon Attila - Kovács Attila: Gazdaság és nacionalizmus. Földreformok az utódállamokban. In: Kisebbségi magyar közösségek a 20. században (Szerk. Bárdi Nándor - Fedinec Csilla - Szarka László). Budapest, MTA Kisebbségkutató Intézet, 2008. 118-123.

REGIO 26. évf. (2018) 1. szám 120-130. 
Lendva-vidékhez) a magyar etnikai tömb megbontása volt, Szakál Imre kötetéből is kiderül, hogy ezen céljukat a túlbürokratizált és forráshiányos állapot miatt nem érték el. A telepítések kezdetben csekély hatást gyakoroltak a régió etnikai, nyelvi viszonyainak változására, noha a korábbi egybefüggő nyelvhatárok mozaikszerüvé válása már ennek hatására elkezdődött.

A körképből, a korábbi feldolgozásokból egyértelmüen kivehető, hogy a háborús helyzet okozta hadigazdálkodás, a társadalmi és gazdasági viszonyok gyökeres átalakulása, majd a háború végét követő, a térség történetét alapjaiban megváltoztató szovjetizálás nélkül a telepítések döntő többsége kudarcba fulladt tervként vonult volna be nemcsak a szakemberek, de a telepesek utódainak tudatába is. A közép-európai földreformok és az azokhoz kapcsolódó telepítések bár csekély mértékben segítettek enyhíteni a mezőgazdasági népesség esélyegyenlőtlenségét, döntő eredményre nem vezettek.

Szakál Imre kötetének tanulsága, mely részben a recenzens egyik, a régiót érintő alaphipotézise is: talán a folytonos változást akaró aktuális helyi hatalom a fejlödés legnagyobb gátja KeletKözép-Európában?

\section{Felhasznált irodalom}

Bartha Ákos: A két világháború közti csehszlovák, jugoszláv és román földbirtokrendezés. Valóság, 2012. 10. 96-112.

Dolmányos István: A kelet-európai földreformok néhány problémája (1917-1939). V. Románia. Agrártörténeti Szemle, 1963. 4. 484504.

Dolmányos István: A kelet-európai földreformok néhány problémája (1917-1939). VI. Jugoszlávia. Agrártörténeti Szemle, 1964. 3-4. 347-365.

Dolmányos István: A kelet-európai földreformok néhány problémája (1917-1939). IV. Csehszlovákia. Agrártörténeti Szemle, 1963. 3. 361-378.

Kovács Attila: Földreform és kolonizáció a Lendva-vidéken a két világháború között. Lendva, 2004.

REGIO 26. évf. (2018) 1. szám 120-130. 
Magyarország földbirtokosai és földbérlöi. Budapest, Magyar Királyi Központi Statisztikai Hivatal, 1937.

Mák Ferenc: A délvidéki kolonizáció és az agrárreform (19181941). In: Mák Ferenc: Vesztegzár. Méry Ratio-KisebbségekértPro Minoritate Alapítvány, 2013. 5-84.

Opra Pál: Erdély lakosságának foglalkozások szerinti megoszlása az 1930-as népszámlálási adatok alapján. Pro Minoritate, 2010. nyár, 29-40.

Simon Attila: Telepesek és telepes falvak Dél-Szlovákiában a két világháború között. Somorja, Fórum Kisebbségkutató Intézet, 2009.

Simon Attila - Kovács Attila: Gazdaság és nacionalizmus. Földreformok az utódállamokban. In: Kisebbségi magyar közösségek a 20. században (Szerk. Bárdi Nándor - Fedinec Csilla - Szarka László). Budapest, MTA Kisebbségkutató Intézet, 2008.

Sipos József: A Nagyatádi-féle földreform, 1920. Rubicon, 2010. 45. 78-81.

REGIO 26. évf. (2018) 1. szám 120-130. 